\title{
Editorial: Marine Aquaculture Impacts on Marine Biota
}

\section{OPEN ACCESS}

Edited and reviewed by:

Yngvar Olsen,

Norwegian University of Science and

Technology, Norway

${ }^{*}$ Correspondence:

Margarida Casadevall

margarida.casadevall@udg.edu

TORCID:

Margarida Casadevall orcid.org/0000-0002-7172-3682

Conxi Rodríguez-Prieto orcid.org/0000-0003-4935-1250

Jordi Torres

orcid.org/0000-0002-4999-0637

Catarina Eira

orcid.org/0000-0003-2735-6034

Michel Marengo

orcid.org/0000-0001-8419-5076

Pierre Lejeune

orcid.org/0000-0002-2419-4896

Roberto Merciai

orcid.org/0000-0003-4051-5730

Jonathan Richir

orcid.org/0000-0001-5890-5724

Specialty section:

This article was submitted to Marine Fisheries, Aquaculture and

Living Resources,

a section of the journal

Frontiers in Marine Science

Received: 08 October 2020

Accepted: 08 February 2021

Published: 26 February 2021

Citation:

Casadevall M, Rodríguez-Prieto C

Torres J, Eira C, Marengo M,

Lejeune P, Merciai R and Richir J

(2021) Editorial: Marine Aquaculture

Impacts on Marine Biota.

Front. Mar. Sci. 8:615267.

doi: 10.3389/fmars.2021.615267

\begin{abstract}
Margarida Casadevall ${ }^{1 *}$, Conxi Rodríguez-Prieto ${ }^{1+}$, Jordi Torres ${ }^{2 t}$, Catarina Eira ${ }^{3 \dagger}$, Michel Marengo ${ }^{4 \dagger}$, Pierre Lejeune ${ }^{4 t}$, Roberto Merciai ${ }^{1+}$ and Jonathan Richir ${ }^{5,6 t}$

${ }^{1}$ Departament de Ciències Ambientals, University of Girona, Girona, Spain, ${ }^{2}$ Departament de Biologia, Sanitat i Medi Ambient, University of Barcelona, Barcelona, Spain, ${ }^{3}$ Centro de Estudos do Ambiente e do Mar (CESAM), Department of Biology, University of Aveiro, Aveiro, Portugal, ${ }^{4}$ Station de Recherches Sous-Marines et Océanographiques (STARESO), Calvi, France, ${ }^{5}$ Chemical Oceanography Unit, FOCUS, University of Liège, Liège, Belgium, ${ }^{6}$ Laboratory of Oceanology, FOCUS, University of Liège, Liège, Belgium
\end{abstract}

Keywords: marine aquaculture, wild organism, pollution, chemical, organic waste, water quality, impact, restoration

\section{Editorial on the Research Topic}

\section{Marine Aquaculture Impacts on Marine Biota}

Marine aquaculture provides undoubted economic benefits and diverts a proportion of fishing pressure on wild stocks. However, it is known to strongly impact marine life (Tacon and Forster, 2003) with the Mediterranean region, which is densely populated and urbanized with a strong demand for seafood, especially sensitive to marine aquaculture pressures (Colloca et al., 2017; Holon et al., 2018). This awareness led the Center for Mediterranean Cooperation of the International Union for Conservation of Nature to set up a working group in 2004. This was originally named "Aquaculture and Environment" and made up of aquaculture specialists from around the Mediterranean Sea; their work resulted in the publication in 2007 of a guide on the sustainable development of marine aquaculture (IUCN-Med, 2007). That same year, considering marine aquaculture was a major threat to the coastal environment, the Mediterranean Science Commission dedicated a workshop to the impact of this activity on Mediterranean coastal ecosystems (CIESM, 2007).

Dempster and Holmer (2010) assessed the scientific literature addressing environmental impacts and dependencies of aquaculture. They identified many papers, published between 2007 and 2008 in a significant number of journals that had studied the issue. To bring together scientists around a common international and interdisciplinary forum, these scientists launched a new journal: "Aquaculture Environment Interactions." In recent years, scientific research and knowledge has developed at a rate proportional to the emergence of marine aquaculture facilities. Aquaculture is the fastest-growing food production sector (FAO, 2016), but there are few mandatory production safety measures to manage the impacts. Some reviews have comprehensively identified threats linked to marine aquaculture. For example, Holmer (2010) described the environmental issues of fish farming in offshore waters and, for the Mediterranean, Grigorakis and Rigos (2011) evaluated the effects of aquaculture on environmental and public welfare.

Marine aquaculture not only has adverse effects on the aquatic environment, but also on the associated biota. Among the little scientific work that has addressed the biota issue to date, stands up the review of Callier et al. (2018) on mobile wild organisms' attraction and avoidance in relation to aquaculture, or the global meta-analysis of Barrett et al. (2019) on the impacts of aquaculture on wildlife. Currently available scientific observations cannot clearly identify the positive or negative effects of marine aquaculture on wildlife. 
Because of this limited scientific knowledge, we felt the time was ripe for a special issue to bring together recent research on the impacts of marine aquaculture on marine biota-with particular emphasis on the Mediterranean as a laboratory in this assessment-and on proposed mitigation measures to reduce the potential negative effects.

New initiatives are needed to make marine aquaculture more environmentally-responsible and sustainable. In this sense, Restorative Shellfish Mariculture (RSM), especially the most conservation-oriented RSM strategies (e.g., habitat restoration, reintroduction of locally extinct endangered species) have the potential to generate greater positive impacts. In their global overview of RSM, Carranza and Ermgassen identify emergent patterns across species and/or ecoregions, based on experiences developed worldwide over the last decades. In contrast, there is no shortage of examples of shellfish aquaculture with negative environmental consequences. As an example, Šegvić-Bubić et al. analyse the impact of oyster culture in wild Mediterranean oyster populations. They report oyster farming and human-mediated spat translocation may pose an environmental risk due to the genetic erosion of wild counterparts and spread of disease. Also, Boudouresque et al. argue shellfish marine aquaculture is the major source of exotic macrophyte species in to the Mediterranean.

In sediments, group of organisms such as nematodes may contribute to the recycling of fish farm-derived organic matter, as emphasized by Grego et al. using carbon stable isotope signatures. Also, elevated microbial degradation of organic compounds in fish farm sediments increases pore water nutrient concentrations. By modeling the impact assessment of a fish farm development in an ultra-oligotrophic setting, Livne et al. suggest that the sediment condition and the increase in apex predators that are attracted are relevant indicators for ecosystem stability. To limit apex predator attraction, these authors suggest developing automated discard and dead fish removal systems at the base of a cage. The attraction to, and deleterious effects of offshore farms on wild fauna are highlighted in the study of Casadevall et al.. They report a tendency to find anomalous specimens of Diplodus sargusinedible tough fish-around fish farms and commercial and industrial ports and hypothesize that pollution could be a driver of the flesh anomaly.

Not only is the sediment microbial activity but the prokaryotic community composition underneath fish cages related to fish biomass and organic enrichment over the course of fish production, as reported by Quero et al.. Although other factors (e.g., seasonality, hydrodynamic conditions) may contribute to the prokaryotic assemblage' variations, their study is useful to assess the impact of intensive marine aquaculture on the surrounding environment. The production area hydrodynamic regime is an important factor to reduce the detrimental impacts on local water quality. According to Gomes et al., the establishment of fish farms in locations with low water residence time would avoid costly approaches aiming to reduce habitat degradation. Finally, Tičina et al. review the impacts on marine biota in oligotrophic environments of the Mediterranean, at different spatial scales, and provide useful information for policy makers, managers and other stakeholders. These authors assert that well-balanced and properly managed marine aquaculture operations should not significantly alter the environment. This concluding statement should, therefore, be the standard for aquaculture development.

Three messages arise from this e-book. Firstly, the identification of potentially suitable sites for the installation of aquaculture facilities should rely on an integrated approach that considers the ecological, environmental, socio-cultural, economic, and technological aspects. Secondly, preliminary impact studies and the use of indicator organisms, from bacteria to fish, should make it possible to minimize the adverse effects of aquaculture. Thirdly, the adjustment of aquaculture practices according to the results of the aforementioned aspects should maximize the sustainability of the activity. The Research Topic focuses on fish aquaculture in the Mediterranean, with shellfish also mentioned; however, the message it conveys can be applied to other areas of activity, such as the development of seaweed aquaculture. In particular, the growing salmon aquaculture industry might benefit from the flow of information of this e-book, in addition to, for example, the recent work of Amundsen and Osmundsen (2018) and Valenti et al. (2018) compiling sustainability indicators, including environmental, for salmon aquaculture. Although not established in the Mediterranean, salmon aquaculture is by far the most important sector of aquaculture production in Europe (48.3\% of relative biomass production in 2014; FAO, 2017), so requires particular attention.

The three messages of this e-book also address recommendations of international's European policies, including the Water Framework Directive (EC, 2000) and the Marine Strategy Framework Directive (EC, 2008). They also address recommendations of specific policies, including the Environmental Impact Assessment Directive (EC, 2001) and the Strategic Environmental Assessment Directive (EC, 2012); they stipulate that any aquaculture plan, programme or project must consider, before development, environmental issues in order to avoid or minimize negative impacts on the marine environment. The development of aquaculture must also comply with the Maritime Spatial Planning Directive (EC, 2014) that aims to promote sustainable development and use of marine resources, through the establishment of maritime spatial plans in each Member State by 2021; i.e., this year. Following the recommendations of this e-book based on the scientific knowledge, and meeting the obligations of Directives should enable the long term growth of marine aquaculture in the Mediterranean and further afield by safeguarding wild stocks and limiting the harmful impacts on environment and biota.

\section{AUTHOR'S NOTE}

JR is a postdoctoral researcher at the Fonds National de la Recherche Scientifique (FNRS). 


\section{AUTHOR CONTRIBUTIONS}

MC and JR wrote the editorial. CR-P, JT, MM, PL, and RM contributed to review and correct the editorial. All authors approved the submitted version.

\section{REFERENCES}

Amundsen, V. S., and Osmundsen, T. C. (2018). Sustainability indicators for salmon aquaculture. Data Brief 20, 20-29. doi: 10.1016/j.dib.2018.07.043

Barrett, L. T., Swearer, S. E., and Dempster, T. (2019). Impacts of marine and freshwater aquaculture on wildlife: a global meta-analysis. Rev. Aquacult. 11, 1022-1044. doi: 10.1111/raq.12277

Callier, M. D., Byron, C. J., Bengtson, D. A., Cranford, P. J., Cross, S. F., Focken, U., et al. (2018). Attraction and repulsion of mobile wild organisms to finfish and shellfish aquaculture: a review. Rev. Aquacult. 10, 924-949. doi: 10.1111/raq. 12208

CIESM (2007). CIESM Workshop Monographs Impact of Mariculture on Coastal Ecosystems. Lisboa. 21-24.

Colloca, F., Scarcella, G., and Libralato, S. (2017). Recent trends and impacts of fisheries exploitation on Mediterranean stocks and ecosystems. Front. Marine Sci. 4:244. doi: 10.3389/fmars.2017.00244

Dempster, T., and Holmer, M. (2010). Introducing the new multidisciplinary journal aquaculture environment interactions. Aquacult. Environ. Interact. 1, i-ii. doi: $10.3354 /$ aei 0000 i

EC (2000). Directive 2000/60/EC of the European Parliament and of the Council of 23 October 2000 establishing a framework for Community action in the field of water policy. OJ. L. 327:73. Available online at: http://data.europa.eu/eli/dir/ $2000 / 60 /$ oj

EC (2001). Directive 2001/42/EC of the European Parliament and of the Council of 27 June 2001 on the assessment of the effects of certain plans and programmes on the environment. OJ. L. 197, 30-37. Available online at: http://data.europa. eu/eli/dir/2001/42/oj

EC (2008). Directive 2008/56/EC of the European Parliament and of the Council of 17 June 2008 establishing a framework for community action in the field of marine environmental policy (Marine Strategy Framework Directive). OJ. $L$. 164, 19-40. Available online at: http://data.europa.eu/eli/dir/2008/56/oj

EC (2012). Directive 2011/92/EU of the European Parliament and of the Council of 13 December 2011 on the assessment of the effects of certain public and private projects on the environment. OJ. L. 26, 1-21. Available online at: https://eurlex.europa.eu/eli/dir/2011/92/oj

EC (2014). Directive 2014/89/EU of the European Parliament and of the Council of 23 July 2014 establishing a framework for maritime spatial planning. OJ. L. 257, 135-145. Available online at: https://eur-lex.europa.eu/eli/dir/2014/89/oj

\section{ACKNOWLEDGMENTS}

Authors are grateful to Prof. Gordon J. Watson and Dr. Simon Bray for their proofreading of the editorial, and to the Editor Prof. Y. Olsen for valuable suggestions on a previous version of the editorial.

FAO (2016). FAO Yearbook. Fishery and Aquaculture Statistics. Rome.

FAO (2017). Regional Review on Status and Trends in Aquaculture Development in Europe - 2015. Rome: FAO Fisheries and Aquaculture Circular No. 1135/1. p. 52.

Grigorakis, K., and Rigos, G. (2011). Aquaculture effects on environmental and public welfare - the case of Mediterranean mariculture. Chemosphere 85, 899-919. doi: 10.1016/j.chemosphere.2011.07.015

Holmer, M. (2010). Environmental issues of fish farming in offshore waters: Perspectives, concerns and research needs. Aquacult. Environ. Interact. 1, 57-70. doi: 10.3354/aei00007

Holon, F., Marre, G., Parravicini, V., Mouquet, N., Bockel, T., Descamp, P., et al. (2018). A predictive model based on multiple coastal anthropogenic pressures explains the degradation status of a marine ecosystem: implications for management and conservation. Biol. Conserv. 222, 125-135. doi: 10.1016/j.biocon.2018. .006

IUCN-Med (2007). Guide for the Sustainable Development of Mediterranean Aquaculture. Interaction Between Aquaculture and the Environment. Aquaculture (IUCN, Glan). Available online at: https://www.iucn.org/ sites/dev/files/import/downloads/acua_en_final.pdf

Tacon, A. G. J., and Forster, I. P. (2003). Aquafeeds and the environment: policy implications. Aquaculture 226, 181-189. doi: 10.1016/S0044-8486(03)00476-9

Valenti, W. C., Kimpara, J. M., de Lima Preto, B., and MoraesValenti, P. (2018). Indicators of sustainability to assess aquaculture systems. Ecol. Indicators 88, 402-413. doi: 10.1016/j.ecolind.2017. 12.068

Conflict of Interest: The authors declare that the research was conducted in the absence of any commercial or financial relationships that could be construed as a potential conflict of interest.

Copyright (c) 2021 Casadevall, Rodríguez-Prieto, Torres, Eira, Marengo, Lejeune, Merciai and Richir. This is an open-access article distributed under the terms of the Creative Commons Attribution License (CC BY). The use, distribution or reproduction in other forums is permitted, provided the original author(s) and the copyright owner(s) are credited and that the original publication in this journal is cited, in accordance with accepted academic practice. No use, distribution or reproduction is permitted which does not comply with these terms. 